\title{
11. Relation of Floppy Eyelid Syndrome with Obstructive Sleep Apnea
}

\author{
Gevşek Gözkapağı Sendromu ile Obstrüktif Uyku Apnesi İlişkisi
}

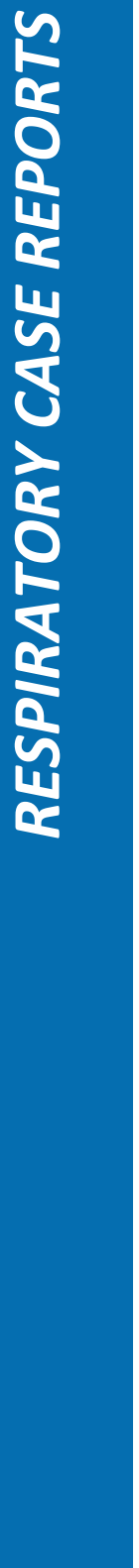

To The Editor,

A 76-year-old man was referred to the department of chest diseases due to floppy eyelid syndrome (FES) by an ophthalmologist (Figure 1A). The patient had snoring and daytime fatigue without any comorbidity. His physical examination revealed Class 2 Mallampati with an Epworth scale score of 8. His body mass index was $30.1 \mathrm{~kg} / \mathrm{m}^{2}$ and the patient underwent the polysomnography test (Figure 1B). The apnea-hypopnea index (AHI) was 33.8/h throughout the nighttime. The patient was diagnosed with severe obstructive sleep apnea syndrome (OSAS) and his symptoms improved with automatic continuous positive airway pressure (CPAP) treatment at $9 \mathrm{cmH}_{2} \mathrm{O}$ pressure.
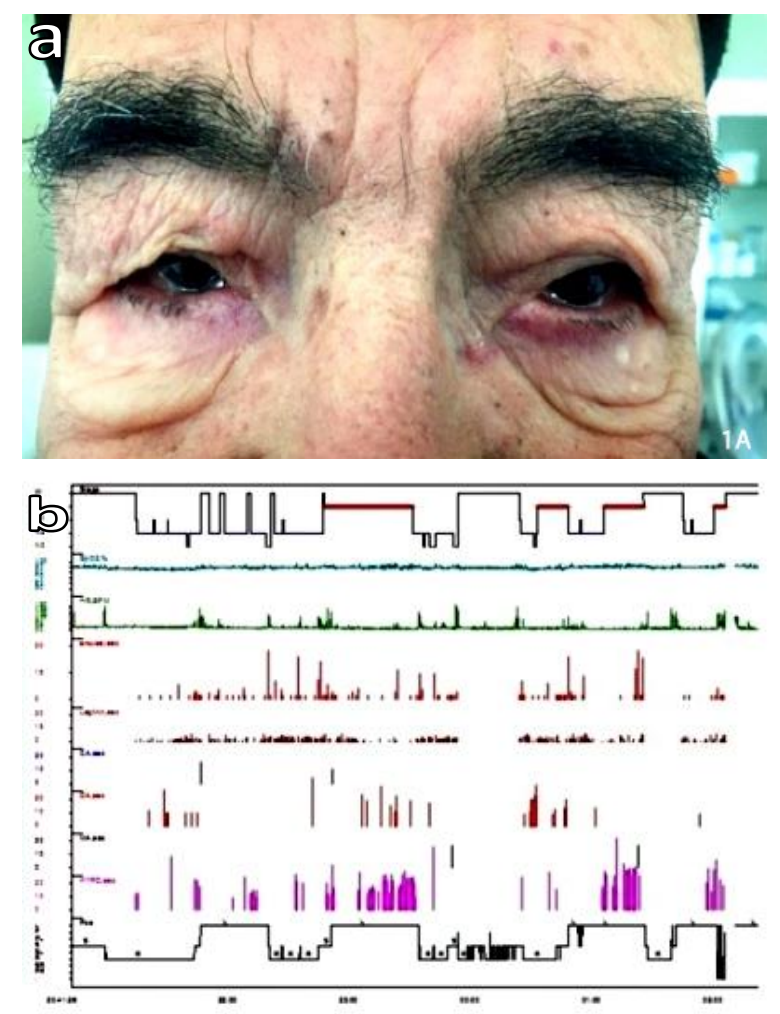

Figure 1a and b: A 76-year-old men with floppy eyelid syndrome (a), the hypnogram of the case (b)

Floppy eyelid syndrome is a clinical entity which has already been extensively investigated in terms of clinical characteristics, local and systemic associations, and treatment since its first description (1). Recent studies have suggested a relationship between OSAS and FES (2). The prevalence of OSAS in patients with FES has been reported to range from $96 \%$ to $100 \%$ in two retrospective case series performed by McNab $(3,4)$. These studies evaluating the prevalence of FES in patients with OSAS demonstrated a relatively low prevalence, ranging from $4.5 \%$ to $5.0 \%(3,5)$. Also, Acar et al. (6) reported high rates and stages of FES in patients with advanced $\mathrm{AHI}$ scores in 280 patients in a sleep clinic, and explained the mechanism of tissue mechanic by hypoxemia.

In general, patients with FES presents with nonspecific irritation, foreign body sensation, mucous discharge, dryness, redness, photosensitivity, eyelid swelling, and vision impairment (7). Although it has not been clearly understood yet, it has been reported to be associated with some systemic and ophthalmic diseases such as obesity, OSAS, ischemic heart disease, skin disorders, connective tissue disorders, corneal and eyelids abnormalities, glaucoma, and hypertension (8). A genetically predisposition, such as genetic abnormalities in collagen, elastin, or both, associated with age and sleeping patterns, have been also postulated. Connective tissue disorder may explain the coexistence of FES and OSAS. Redundancy of tissue in the tarsal plate of lateral canthal tendons may contribute to the development of FES. Similarly, the excess of oropharyngeal tissues results in the upper airway obstruction during sleeping in particular (9).

Irrespective of the underlying mechanism of the disease pathogenesis, the main characteristic of the OSAS remains the increased laxity of the eyelid, and the evaluation can be useful in terms of early diagnosis as in our case. Many OSAS cases are not 
diagnosed in time, and a full ophthalmologic as sessment consisting of a careful lid laxity evaluation can contribute to the early diagnosis.

\section{Ahmet Cemal Pazarlı', Yusuf Güneş ${ }^{2}$, Mehmet Akif Abakay ${ }^{3}$}

'Department of Chest Diseases, Elbistan State Hospital, Kahramanmaraş, Turkey

${ }^{2}$ Department of Ophthalmology, Elbistan State Hospital, Kahramanmaras, Turkey

${ }^{3}$ Department of Otorhinolaryngology, Elbistan State Hospital, Kahramanmaraş, Turkey

Correspondence (iletişim): Ahmet Cemal Pazarlı, Department of Chest Diseases, Elbistan State Hospital, Kahramanmaraş, Turkey

e-mail: cpazarli@hotmail.com

\section{CONFLICTS OF INTEREST}

None declared.

\section{AUTHOR CONTRIBUTIONS}

Concept - A.C.P., Y.G., M.A.A.; Planning and Design - A.C.P., Y.G., M.A.A.; Supervision - M.A.A., A.C.P., Y.G.; Funding - A.C.P., Y.G., M.A.A.; Materials - Y.G.; Data Collection and/or Processing A.C.P., M.A.A.; Analysis and/or Interpretation A.C.P., M.A.A.; Literature Review - Y.G., M.A.A.; Writing - A.C.P.; Critical Review - A.C.P., M.A.A.

\section{YAZAR KATKILARI}

Fikir - A.C.P., Y.G., M.A.A.; Tasarım ve Dizayn A.C.P., Y.G., M.A.A.; Denetleme - M.A.A., A.C.P., Y.G.; Kaynaklar - A.C.P., Y.G., M.A.A.; Malzemeler - Y.G.; Veri Toplama ve/veya İşleme - A.C.P., M.A.A.; Analiz ve/veya Yorum - A.C.P., M.A.A.; Literatür Taraması - Y.G., M.A.A.; Yazıyı Yazan A.C.P.; Eleştirel İnceleme - A.C.P., M.A.A.

\section{REFERENCES:}

1. Beis PG, Brozou CG, Gourgoulianis KI, Pastaka C, Chatzoulis DZ, Tsironi EE. The floppy eyelid syndrome: evaluating lid laxity and its correlation to sleep apnea syndrome and body mass index. ISRN Ophthalmol 2012; 2012:650892. [CrossRef]

2. Chambe J, Laib S, Hubbard J, Erhardt C, Ruppert E, Schroder C, et al. Floppy eyelid syndrome is associated with obstructive sleep apnoea: a prospective study on 127 patients. J Sleep Res 2012; 21,308-15. [CrossRef]

3. McNab AA. Floppy eyelid syndrome and obstructive sleep apnea. Ophthal Plast Reconstr Surg 1997; 13:98-114. [CrossRef]

4. McNab AA. The eye and sleep. Clin Experiment Ophthalmol 2005; 33:1 17-25. [CrossRef]

5. Karger RA, White WA, Park WC, Rosales AG, McLaren JW, Olson EJ, et al. Prevalence of floppy eyelid syndrome in obstructive sleep apnea-hypopnea syndrome. Ophthalmology 2006; 113:1669-74. [CrossRef]

6. Acar M, Fırat H, Acar U, Ardıç S. Ocular surface assessment in patients with obstructive sleep apneahypopnea syndrome. Sleep Breath 2013; 17: 583-8. [CrossRef]

7. Leibovitch I, Selva D. Floppy eyelid syndrome: clinical features and the association with obstructive sleep apnea. Sleep Med 2006; 7:117-22. [CrossRef]

8. Miyamoto C, Espı Drito Santo LC, Roisman L, Moreno PAM, Cariello AJ, Osaki MH. Floppy eyelid syndrome: review. Arq Bras Oftalmol 2011; 74:64-6.

9. Liu DT, Di Pascuale MA, Sawai J, Gao YY, Tseng SC. Tear film dynamics in floppy eyelid syndrome. Invest Ophthalmol Vis Sci 2005; 46:1 188-94. [CrossRef] 